\title{
Factors Affecting Inadequate Empirical Antimicrobial Therapy and the Clinical Course of Upper Urinary Tract Infections in Elderly Patients: A Multicenter Study
}

\author{
Yaşlı Hastalardaki Üst Üriner Sistem Enfeksiyonlarında Yetersiz Ampirik Antibiyoterapiye ve \\ Klinik Gidişe Etki Eden Faktörler: Çok Merkezli Bir Çalışma
}

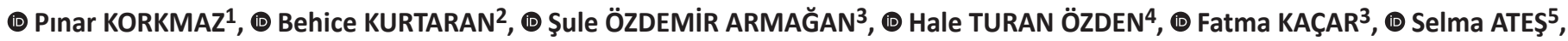

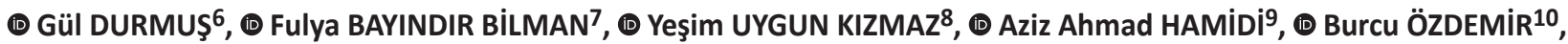
(1) Aslıhan BURCU YIKILGAN ${ }^{11}$, ๑ PInar FIRAT ${ }^{11}$, ๑ Asuman iNAN ${ }^{12}$, ๑ Gülay OKAY ${ }^{13}$, ๑ Mehmet Emirhan IŞIK ${ }^{8}$, ๑ Ayşe BUT ${ }^{10}$,

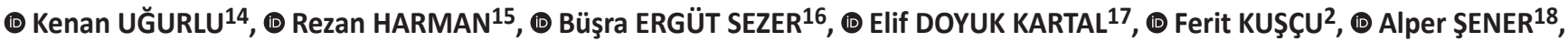

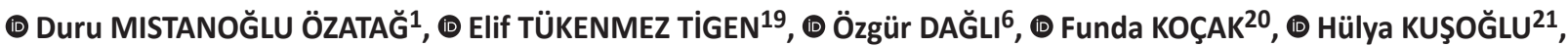

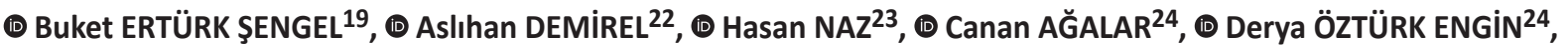

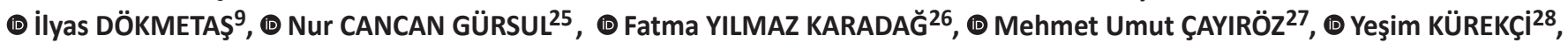

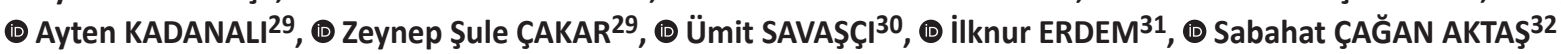

1 Kütahya Health Sciences University Turkey, Faculty of Medicine, Department of Infectious Diseases and Clinical Microbiology, Kütahya, Turkey ${ }^{2}$ Çukurova University Faculty of Medicine, Department of Infectious Diseases and Clinical Microbiology, Adana, Turkey ${ }^{3}$ Konya Training and Research Hospital, Clinic of Infectious Diseases and Clinical Microbiology, Konya, Turkey 4Başkent University Faculty of Medicine, Department of Infectious Diseases and Clinical Microbiology, Konya, Turkey ${ }^{5}$ Kahramanmaraş Sütçü Imam University Faculty of Medicine, Department of Infectious Diseases and Clinical Microbiology, Kahramanmaraş, Turkey ${ }^{6}$ Bursa Yüksek ihtisas Training and Research Hospital, Clinic of Infectious Diseases and Clinical Microbiology, Bursa, Turkey 7izmir Menemen State Hospital Clinic of Infectious Diseases and Clinical Microbiology, Izmir, Turkey 8istanbul Koşuyolu Yüksek ihtisas Training and Research Hospital, Clinic of Infectious Diseases and Clinical Microbiology, Istanbul, Turkey 9istanbul Şişli Hamidiye Etfal Training and Research Hospital, Clinic of Infectious Diseases and Clinical Microbiology, Istanbul, Turkey ${ }^{10}$ Ankara Numune Training and Research Hospital, Clinic of Infectious Diseases and Clinical Microbiology, Ankara, Turkey 11 University of Health Sciences Turkey, Ankara Keçiören Training and Research Hospital, Clinic of Infectious Diseases and Clinical Microbiology, Ankara, Turkey 12istanbul Haydarpaşa Numune Training and Research Hospital, Clinic of Infectious Diseases and Clinical Microbiology, Istanbul, Turkey ${ }_{13}^{13}$ Bezmialem University Faculty of Medicine, Department of Infectious Diseases and Clinical Microbiology, istanbul, Turkey 1425 Aralık State Hospital, Clinic of Infectious Diseases and Clinical Microbiology, Gaziantep, Turkey

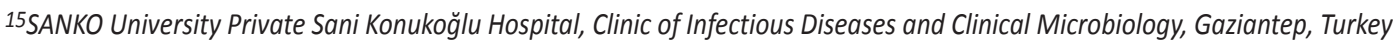
${ }^{16}$ Çorlu State Hospital, Clinic of Infectious Diseases and Clinical Microbiology, Tekirdağ, Turkey ${ }^{17}$ Eskişehir Osmangazi University Faculty of Medicine, Department of Infectious Diseases and Clinical Microbiology, Eskişehir, Turkey ${ }_{18}$ Çanakkale Onsekiz Mart University Faculty of Medicine, Department of Infectious Diseases and Clinical Microbiology, Çanakkale, Turkey ${ }_{19}^{19}$ Marmara University Pendik Training and Research Hospital, Clinic of Infectious Diseases and Clinical Microbiology, İstanbul, Turkey ${ }^{20}$ Başakşehir State Hospital, Clinic of Infectious Diseases and Clinical Microbiology, İstanbul, Turkey

${ }^{21}$ Acibadem Mehmet Ali Aydınlar University Faculty of Medicine, Department of Infectious Diseases and Clinical Microbiology, Istanbul, Turkey

22Demiroğlu Bilim University, Florence Nightingale Hospital, Clinic of Infectious Diseases and Clinical Microbiology, İstanbul, Turkey
\end{abstract}

Cite this article as: Korkmaz $P$, Kurtaran $B$, Özdemir Armağan Ş, Turan Özden $H$, Kaçar $F$, Ateş $S$, Durmuş G, Bayındır Bilman $F$, Uygun Kızmaz $Y$, Ahmad Hamidi $A$, Özdemir B, Yıkılgan AB, Fırat P, İnan A, Okay G, Işık ME, But A, Uğurlu K, Harman R, Ergüt Sezer B, Doyuk Kartal E, Kuşçu F, Şener A, Mıstanoğlu Özatağ D, Tükenmez Tigen E, Dağıı Ö, Koçak F, Kuşoğlu H, Ertürk Şengel B, Demirel A, Naz H, Ağalar C, Öztürk Engin D, Dökmetaş I, Cancan Gürsul N, Yılmaz Karadağ F, Çayıröz MU, Kürekçi Y, Kadanalı A, Çakar ZŞ, Savaşçı Ü, Erdem I, Çağan Aktaş S. Factors Affecting Inadequate Empirical Antimicrobial Therapy and the Clinical Course of Upper Urinary Tract Infections in Elderly Patients: A Multicenter Study. Mediterr J Infect Microb Antimicrob. 2020;9:5.

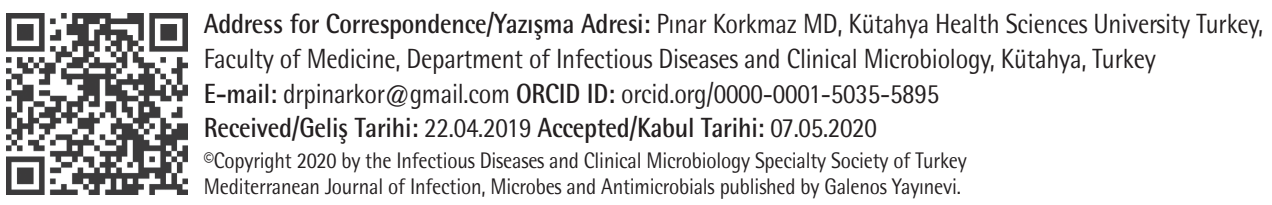

Presented in: This study was presented (orally) in $7^{\text {th }}$ EKMUD Congress. 
${ }^{23}$ Kocaeli Derince Training and Research Hospital, Clinic of Infectious Diseases and Clinical Microbiology, Kocaeli, Turkey

${ }^{24}$ University of Health Sciences Turkey, Fatih Sultan Mehmet Training and Research Hospital, Clinic of Infectious Diseases and Clinical Microbiology, istanbul, Turkey

${ }^{25}$ Çanakkale State Hospital, Clinic of Infectious Diseases and Clinical Microbiology, Çanakkale, Turkey

${ }^{26}$ istanbul Medeniyet University Training and Research Hospital, Department of Infectious Diseases and Clinical Microbiology, Istanbul, Turkey

27izmir Bozyaka Training and Research Hospital, Clinic of Infectious Diseases and Clinical Microbiology, izmir, Turkey

28Arnavutköy State Hospital, Clinic of Infectious Diseases and Clinical Microbiology, İstanbul, Turkey

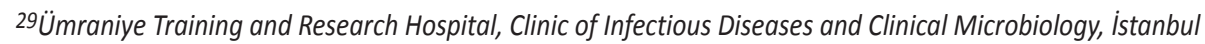

30University of Health Sciences Turkey, Gülhane Training and Research Hospital, Clinic of Infectious Diseases and Clinical Microbiology, Ankara, Turkey

${ }^{31}$ Namık Kemal University Faculty of Medicine, Department of Infectious Diseases and Clinical Microbiology, Tekirdağ, Turkey

32University of Health Sciences Turkey, Kartal Dr. Lütfi Kırdar Training and Research Hospital, Clinic of Infectious Diseases and Clinical Microbiology, i̇stanbul, Turkey

\section{Abstract}

Introduction: In this study, we aimed to determine the risk factors associated with inadequate empirical antibiotherapy (IEAT) and hospital-related mortality in elderly patients being treated for upper urinary tract infections (UTI).

Materials and Methods: This study included individuals aged 65 years and over who were hospitalized after being diagnosed of communityacquired UTI or community-onset healthcare-associated UTI and followed-up in clinics and/or intensive care units (ICU) of 33 hospitals between March and September 2017.

Results: A total of 525 patients (48\% males; mean age: $76.46 \pm 7.93$ years) were included in the study. Overall, $68.2 \%$ of the patients were hospitalized through the emergency department and 73.9\% of patients were followed-up for pyelonephritis. Gram-negative, Gram-positive, and Gram-negative and positive mix growths were determined in 88\%, 9.3\%, and 2.7\% of urine cultures, respectively. Fifty-six (10.7\%) of the patients died. In multivariate analysis, the presence of chronic obstructive pulmonary disease [Odds ratio (OR): 2.278], age 85 years and over (OR: 2.816), admission to the ICU (OR: 14.831), and IEAT (OR: 2.364) were independent factors that significantly affected mortality. The presence of a urinary catheter, being followed-up in the ICU, benign prostate hypertrophy, use of antibiotics other than piperacillin-tazobactam and carbapenem were determined as independent factors that significantly affected IEAT $(p<0.05)$.

Conclusion: In our study, we found a direct correlation between IEAT and mortality. Therefore, knowing the most frequent microorganisms and antibiotic susceptibility profiles observed in the UTI of elderly patients may help to decrease the mortality and morbidity associated with these infections.

Keywords: Urinary tract infection, empirical, antibiotherapy, mortality

\section{$\ddot{0} z$}

Giriş: Bu çalışma ile üst üriner sistem enfeksiyonu (ÜSE) tanısıyla izlenen yaşı hastalarda yetersiz ampirik antibiyoterapi ve hastane mortalitesi ile ilişkili risk faktörlerinin değerlendirilmesini amaçladık.

Gereç ve Yöntem: Çalışmaya 33 hastanede Mart 2017-Eylül 2017 tarihleri arasında toplum kaynaklı ÜSE ve toplumda gelişen sağlık hizmetleri ile ilişkili ÜSE tanısıyla hospitalize edilerek kliniklerde ve/veya yoğun bakım ünitelerinde takip edilen 65 yaş ve üzeri hastalar dahil edildi.

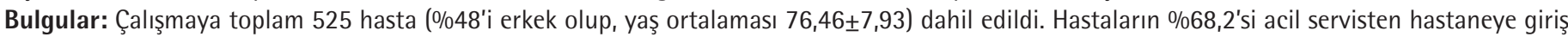
yapılmıştı. Hastaların \%73,9'u piyelonefrit tanısı ile izlenmekteydi. İdrar kültürlerinde Gram-negatif, Gram-pozitif, Gram-negatif ve pozitif üremeler sırasıyla \%88, \%9,3 ve \%2,7 olarak saptandı. Çok değiş̧kenli analizde kronik obstrüktif akciğer hastalığı varlığı [Odds oranı (OR): 2,278], 85 yaş ve üzerinde olma (OR: 2,816), yoğun bakımda yatış (OR: 14,831), yetersiz başlangıç ampirik antibiyoterapi (OR: 2,364), mortalite üzerine etkili bağımsız değişkenler olarak tespit edildi. Üriner kateter varlığı, yoğun bakım ünitesinde izlem, benin prostat hipertrofisi varlığı, piperasilin tazobaktam ve karbapenem harici antibiyotik kullanımı, yetersiz ampirik antibiyoterapi üzerine etkili bağımsız değişkenler olarak saptadık $(p<0,05)$.

Sonuç: Çalışmamızda ampirik tedavinin yetersizliği ile mortalite arasında doğrudan bir ilişki saptadık. Bu nedenle yaşı hastalarda gelişen ÜSE'de en sık görülen mikroorganizmaların duyarlııı profillerinin bilinmesi bu enfeksiyonlara bağlı mortalite ve morbiditenin azaltılmasına yardımcı olabilir.

Anahtar Kelimeler: Üriner sistem enfeksiyonu, ampirik, antibiyoterapi, mortalite

\section{Introduction}

Urinary tract infections (UTIs) are one of the most commonly observed infections in elderly individuals, in whom its incidence is high due to immune senescence and age-related anatomical and physiological changes ${ }^{[1,2]}$. The incidence of UTIs is approximately $10 \%$ in females and $5 \%$ in males aged $>80$ years $^{[3]}$. Furthermore, $15.5 \%$ of hospitalizations occur due to infectious diseases, with UTI-related mortality reported as $6.2 \%$ in individuals aged over 65 years $^{[4]}$.

In community-acquired UTI (CA-UTI), the most commonly isolated bacteria are Escherichia coli, Enterobacter spp., Klebsiella spp., and Proteus spp. However, there has also been an increase in isolates with the potential to develop resistance such as Pseudomonas aeruginosa and Gram-positive microorganisms ${ }^{[3,5]}$. More than one comorbid disease, recurrent 
hospitalizations, chronic use of a urinary catheter, and frequent use of antibiotics account for the development of antibioticresistant bacteria and inadequate empirical antibiotherapy $(\mathrm{IEAT})^{[5,6]}$. Since improvement is provided in clinical parameters such as reduction in mortality and period in intensive care unit when the treatment is initiated with appropriate antibiotherapy in serious infections of the elderly patients, it is important to select an appropriate empirical treatment ${ }^{[7]}$.

Knowing the distribution of microorganisms, resistance patterns in UTIs occurring in the elderly and the factors affecting IEAT and mortality may contribute to improve the clinical course in this population. The present study aimed to determine the risk factors associated with IEAT in elderly patients followedup after being diagnosed with UTI by providing clinical and microbiological data of infection and to further evaluate hospitality-mortality-related risk factors.

\section{Materials and Methods}

\section{Design}

This study included individuals aged 65 years and over who were hospitalized after being diagnosed of CA-UTI or communityonset healthcare-associated UTI (CO-HCA UTI) and followed-up in clinics and/or ICUs of 33 hospitals (13 provinces in Turkey) between March and September 2017. Approval for this study was obtained from the Çukurova University Faculty of Medicine Research Ethics Committee (approval date: 10/02/2017, no: 44). Written informed consent was obtained from the study participants. The study was done in accordance with the "Helsinki Declaration" and "Good Medical Practice Guidelines"[8].

\section{Definitions}

In this study, UTI was defined as a bacterial growth of $>10^{5} \mathrm{CFU} /$ $\mathrm{mL}$ together with the detection of a maximum of two species of microorganisms in the urine culture of a patient with urinary tract symptoms and signs; urinary tract symptoms were defined as fever, new, or exacerbating urgency, new, or exacerbating frequent urination, suprapubic pain, costovertebral angle pain/ tenderness, and otherwise unexplained systemic symptoms, including altered mental status and hypotension $n^{[9,10]}$. Two types of UTI were included in the study: CA-UTI and CO-HCA UTI. Community-onset healthcare-associated urinary tract infections was defined as 1) receiving a medical treatment in a hospital for 48 hours or longer within 90 days before a new hospital admission; 2 ) receiving a medical treatment at home administered by healthcare professionals within 30 days prior to hospital admission; 3) attending a hospital, hemodialysis clinic, or receiving intravenous chemotherapy within 30 days prior to hospital admission; and 4) residing in a nursing home. CAUTI was defined as patients not meeting the criteria for a COHCA UTI ${ }^{[6]}$. Furthermore, sepsis and septic shock were defined according to "The Third International Consensus Definitions for Sepsis and Septic Shock" (Sepsis-3) $)^{[11]}$. Urosepsis was defined as life-threatening organ dysfunction caused by a dysregulated host response to a UTI ${ }^{[11]}$. Organ dysfunction was defined as an acute change in the total Sequential Organ Failure Assessment (SOFA) score by 2 points consequent to the infection ${ }^{[11]}$. The patients with an infectious source other than UTI and whose urine culture had no growth were excluded from the study.

Functional status was categorized as "dependent" or "independent". Dependent functional status was defined as an immobile patient and independent functional status was defined as the ability to walk by himself/herself or with support (walking stick, walker) ${ }^{[12]}$. Inadequate empirical antibiotic therapy was defined as the inefficiency of at least one of antibiotics used in the initial empirical treatment on a growing microorganism ${ }^{[6]}$. Identification and susceptibility testing were performed by automated systems in the centers [VITEC 2 ID-AST Compact System (Biomerieux, France), MALDI-TOF MS (Microflex LT, Bruker Daltonics,. Germany), BD - Phoenix ${ }^{\mathrm{TM}}$ M50 System. Company BD, United Kingdom, Phoenix system (BD, Sparks, $M D, U S A)]$ and conventional methods in two centers. Minimal inhibitor concentrations (MIC) and zone diameter breakpoint criteria were determined according to the MIC and zone diameter distributions of the European Antimicrobial Susceptibility Tests Committee (EUCAST) ${ }^{[13]}$. Extended-spectrum beta-lactamases (ESBL) criteria were determined by following the EUCAST guidelines for the detection of resistance mechanisms (MIC for ceftazidime or cefotaxime tested in combination with clavulanic acid) $)^{[14]}$.

\section{Statistical Analysis}

The Number Cruncher Statistical System (NCSS; 2007 edition; Kaysville, UT, USA) was used for statistical analysis. The MannWhitney $U$ test was used for intergroup comparisons of nonnormally distributed parameters, while the Pearson chi-square test, Fisher's exact test, and Fisher-Freeman-Halton test were used to compare qualitative data. On multivariate analysis, the effects of other risk factors on mortality and the adequacy of the initial treatment were evaluated using the backward logistic regression analysis. $\mathrm{P}<0.05$ was considered as statistically significant.

\section{Results}

\section{Demographic and Clinical Data}

A total of 525 patients (48\% males; mean age: $76.46 \pm 7.93$ years) were included in the study. Overall, $68.2 \%$ of patients were hospitalized through the emergency department; $23.6 \%$ of the patients had a diagnosis of urosepsis, 2.5\% of septic shock, and $12.4 \%$ of malignancy. There was a history of recurrent UTI 
in $146(27.8 \%)$ of the patients and hospitalization rate in the past 12 months was $50.3 \%$. There was a history of antibiotic use in 236 (45\%) of the patients in the past three months. There was a history of genitourinary intervention in $16.4 \%$ of the patients before hospital admission. Table 1 summarizes the demographic data and physical examination and laboratory findings of the study cohort.

\section{Microbiological Data}

Gram-negative, Gram-positive, and Gram-negative and positive mix growths were determined in 88\%, 9.3\%, and $2.7 \%$ of urine cultures, respectively. When the growths were evaluated, two Gram-positive or two Gram-negative growths were not observed simultaneously. Overall, $67.6 \%$ of Gram-negative microorganisms were E. coli, followed by K. pneumoniae (20.6\%). Table 2 presents the growth and distributions of microorganisms in the patients. The antibiotic succeptibility rates of $E$. coli to ertapenem, imipenem, amikacin, cefepime, cefuroxime, ceftazidime, ceftriaxone, ciprofloxacin, levofloxacin, ampicillin/ sulbactam, piperacillin/tazobactam, and colistin were 98.2\%, 99.6\%, 88.6\%, 47.8\%, 43\%, 44.3\%, 42.7\%, 45.7\%, 49.6\%, 32.6 $\%, 71 \%$, and $100 \%$, respectively. The antibiotic succeptibility rates of $K$. pneumoniae to ertapenem, imipenem, amikacin, cefepime, cefuroxime, ceftazidime, ceftriaxone, ciprofloxacin, levofloxacin, ampicillin/sulbactam, piperacillin/tazobactam, and colistin were 88.6\%, 93.8\%, 72.4\%, 33.9\%, 25.9\%, 22.4\%, $26.6 \%, 43.2 \%, 41.9 \%, 12.1 \%, 46.3 \%$, and $92.3 \%$, respectively. The ESBL rate was 56.3\% and 69\% for E. coli and K. pneumoniae, respectively. The antibiotic succeptibility rates of $E$. faecalis to ampicillin, ciprofloxacin, clindamycin, erythromycin, fosfomycin, gentamicin, levofloxacin, linezolid, vancomycin, tigecycline, and teicoplanin were 81\%, 32.3\%, 33.3\%, 44.4\%, 75\%, 71.4\%, $66.7 \%, 100 \%, 100 \%, 100 \%$, and 100\%, respectively. Blood cultures were carried out in 350 (66.7\%) cases and 77 (22\%) were positive. In all of these cases, the microorganisms isolated in blood were the same as those isolated in urine. Figures 1 and 2 present the antimicrobial susceptibility of Gram-negative and Gram-positive microorganisms.

Table 1. Demographic and clinical characteristics

\begin{tabular}{|c|c|c|c|}
\hline \multicolumn{2}{|l|}{ Characteristics n (\%) } & \multicolumn{2}{|l|}{ Characteristics n (\%) } \\
\hline $\begin{array}{l}\text { Age } \\
65-74 \\
75-84 \\
\geq 85\end{array}$ & $\begin{array}{l}228(43.4) \\
203(38.7) \\
94(17.9) \\
\end{array}$ & $\begin{array}{l}\text { Pyelonephritis } \\
\text { Urosepsis } \\
\text { Septic shock }\end{array}$ & $\begin{array}{l}388(73.9) \\
124(23.6) \\
13(2.5) \\
\end{array}$ \\
\hline $\begin{array}{l}\text { Male } \\
\text { Female }\end{array}$ & $\begin{array}{l}252(48) \\
273(52)\end{array}$ & $\begin{array}{l}\text { No catheter } \\
\text { Permanent catheter } \\
\text { Temporary catheter }\end{array}$ & $\begin{array}{l}238(45.3) \\
71(41.1) \\
216(13.5) \\
\end{array}$ \\
\hline Comorbid diseases & & Symptoms & \\
\hline $\begin{array}{l}\text { Diabetes } \\
\text { Coronary artery disease } \\
\text { Chronic renal failure } \\
\text { Cerebrovascular accident } \\
\text { Chronic obstructive pulmonary disease } \\
\text { Congestive heart failure } \\
\text { Solid organ malignant tumor } \\
\text { Hypertension } \\
\text { BPH } \\
\text { Alzheimer's disease } \\
\text { Parkinson's disease } \\
\text { Other }\end{array}$ & $\begin{array}{l}233(44.4) \\
160(30.5) \\
159(30.3) \\
115(21.9) \\
107(20.4) \\
107(20.4) \\
65(12.4) \\
60(11.4) \\
22(4.2) \\
14(2.7) \\
10(1.9) \\
38(7.2)\end{array}$ & $\begin{array}{l}\text { Fatigue } \\
\text { History of fever } \\
\text { Dysuria } \\
\text { Nausea } \\
\text { Abdominal pain } \\
\text { Pelvic pain/side pain } \\
\text { Urgency } \\
\text { Pollakiuria } \\
\text { Altered-state of consciousness } \\
\text { Vomitus } \\
\text { Malnutrition }\end{array}$ & $\begin{array}{l}407(77.5) \\
340(64.8) \\
271(59.7) \\
261(49.7) \\
207(39.4) \\
204(38.9) \\
158(34.8) \\
157(34.6) \\
167(31.8) \\
156(29.7) \\
44(8.4)\end{array}$ \\
\hline $\begin{array}{l}\text { Charlson Comorbidity Index } \\
0-1 \\
2-3 \\
4-5 \\
6-7 \\
\geq 8\end{array}$ & $\begin{array}{l}74.4(14.1) \\
134(25.5) \\
163(31) \\
99(18.9) \\
55(10.5)\end{array}$ & $\begin{array}{l}\text { Physical examination } \\
\text { Fever }\left(>38^{\circ} \mathrm{C}\right) \\
\text { Suprapubic tenderness } \\
\text { Altered-state of consciousness } \\
\text { Hypotension }\end{array}$ & $\begin{array}{l}311(59.2) \\
258(49.1) \\
167(31.8) \\
70(13.3)\end{array}$ \\
\hline
\end{tabular}

'Dependent functional status was defined as immobile patient.

"Independent functional status was defined as the ability to walk himself/herself or with support (walking stick, walker).

$\mathrm{BPH}$ : Benign prostate hypertrophy 


\section{Risk Factors Associated with IEAT}

In the empirical treatment, the most commonly used antibiotic was ceftriaxone $(42.5 \%)$ and the mean duration of treatment was $10.26 \pm 5.24$ days. Table 3 outlines the characteristics of treatment in the patients. When the treatments were evaluated, it was seen that moxifloxacin was initiated in 11 patients $(2.1 \%)$ during the empirical treatment. It was thought that moxifloxacin was initiated in these patients because complaints of UTI were absent or insignificant at admission. Initial antibiotherapy

Table 2. Microorganisms isolated from urine cultures of the patients

\begin{tabular}{l|l}
\hline Microorganism grown in urine culture & \\
Gram-negative & $462(88.0)$ \\
Gram-positive & $49(9.3)$ \\
Gram-positive and -negative & $14(2.7)$ \\
\hline Gram-negative & \\
E. coli & $322(67.6)$ \\
K. pneumoniae & $98(20.6)$ \\
P. aeruginosa & $36(7.6)$ \\
Enterobacter spp. & $6(1.3)$ \\
Proteus spp. & $5(1.1)$ \\
Other & $9(1.8)$ \\
\hline Gram-positive & \\
E. faecalis & $43(68.3)$ \\
S. aureus & $10(15.9)$ \\
Coagulase negative staphylococci & $5(7.9)$ \\
E. faecium & $4(6.3)$ \\
S. mitis & $1(1.6)$
\end{tabular}

a

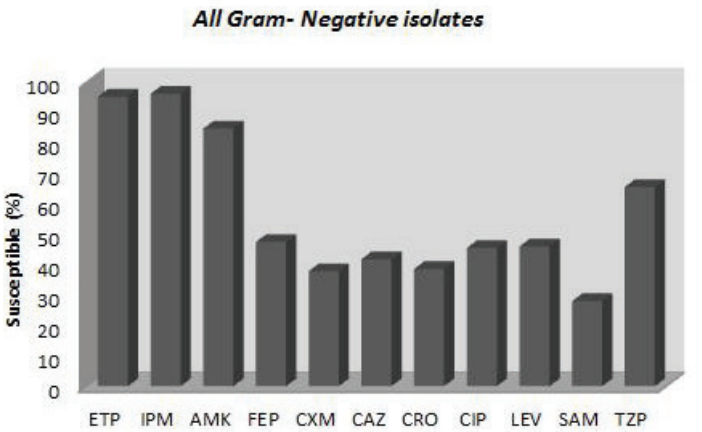

was adequate in $70.3 \%$ of patients. No statistically significant difference was determined between adequacy of the initial antibiotherapy and characteristics including gender, residing in a nursing home or elderly care center, history of hospitalization during previous 12 months, diabetes, chronic renal failure, chronic obstructive pulmonary disease (COPD), cerebrovascular accident, solid organ tumor, hematological malignancy, congestive heart failure, hypertension, Alzheimer's disease, chronic liver disease, Parkinson's disease, hypothyroidism, number of comorbid disease ( $p>0.05)$.

The assessment of patients with and without adequate empirical antibiotherapy revealed IEAT to be significantly higher in patients with advanced age, urosepsis, urinary catheter, functional dependency, coronary artery disease, benign prostat hypertrophy (BPH), and increase in the Charlson Comorbidity Index (CCI) $(\mathrm{p}<0.05)$. Multivariate analysis was performed for all the significant variables in the univariate analysis. The presence of a urinary catheter, admission to the ICU, BPH, and use of antibiotics other than piperacillin-tazobactam and carbapenem were determined as independent factors that significantly affected IEAT ( $p<0.05$; the factors effective on the adequacy of initial antibiotherapy shown in Table 4).

\section{Risk Factors Associated with Mortality}

Fifty-six (10.7\%) of the patients died. No statistically significant difference was found between the patients who died and those who survived in terms of gender, occupation, residing

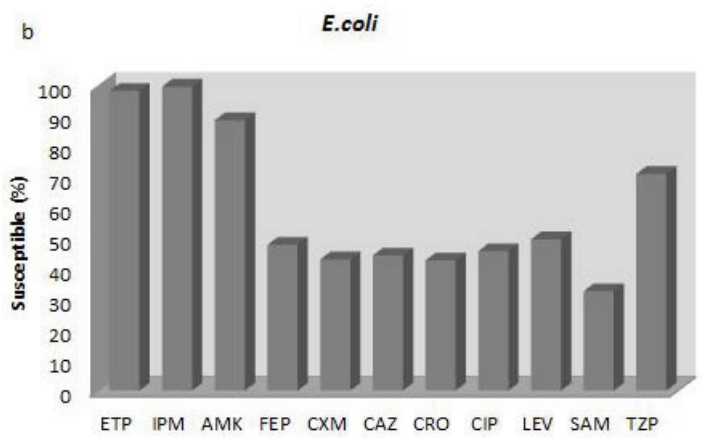

c

K. pneumoniae

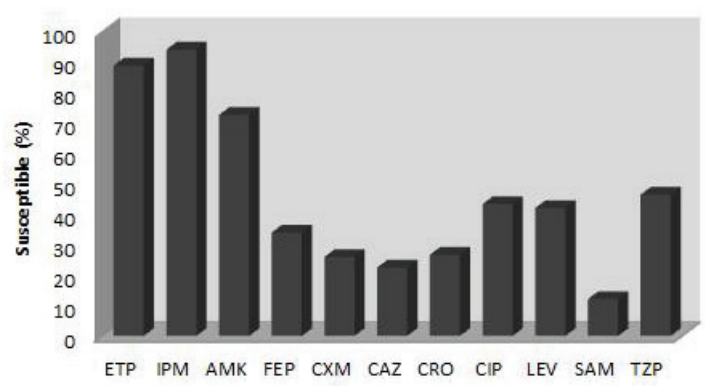

Figure 1. The antimicrobial susceptibility of Gram-negative microorganisms

ETP: Ertapenem, IMP: Imipenem, AMK: Amikacin, FEP: Cefepime, CXM: Cefuroxime, CAZ: Ceftazidime, CRO: Ceftriaxone, CIP: Ciprofloxacin, LEV: Levofloxacin, SAM: Ampicillin/sulbactam, TZP: Piperacillin/tazobactam 
a

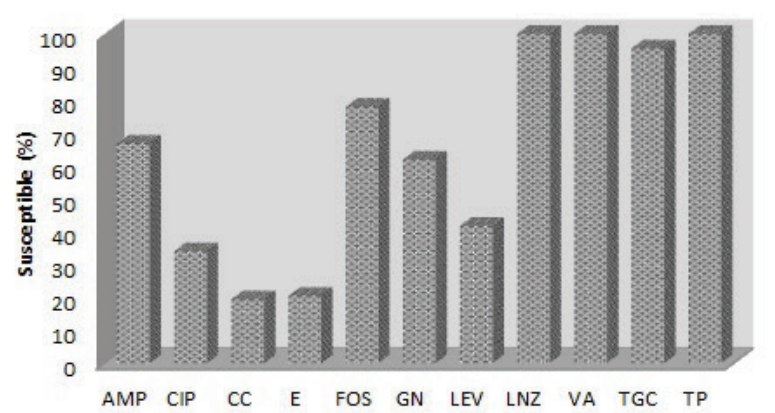

b

E. feacalis

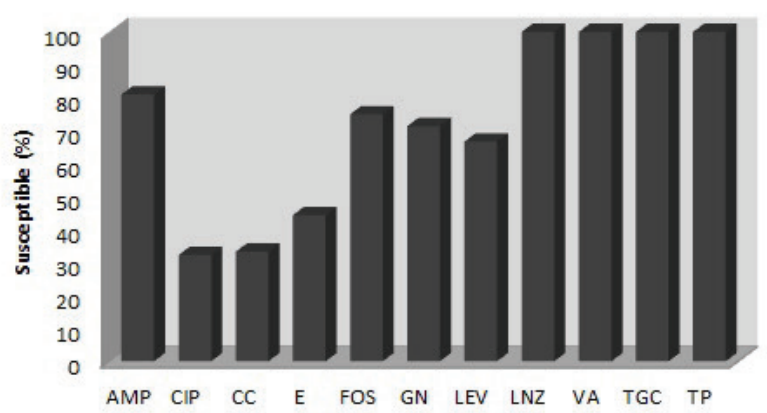

Figure 2. The antimicrobial susceptibility of Gram-positive microorganisms

AMP: Ampicillin, CIP: Ciprofloxacin, CC: Clindamycin, E: Erythromycin, FOS: Fosfomycin, GN: Gentamycin, LEV: Levofloxacin, LNZ: Linezolid, VA: Vancomycin, TGC: Tigecycline, TP: Teicoplanin

Table 3. Characteristics in the patients related to treatment

\begin{tabular}{l|l}
\hline Characteristics & $\mathbf{n}(\%)$ \\
\hline Antibiotic initiated & \\
Ceftriaxone & $223(42.5)$ \\
Ertapenem & $107(20.4)$ \\
Meropenem & $59(11.2)$ \\
Piperacillin-tazobactam & $32(6.1)$ \\
Ciprofloxacin & $44(8.4)$ \\
Ampicillin-sulbactam & $12(2.3)$ \\
Moxifloxacin & $11(2.1)$ \\
Levofloxacin & $5(1.0)$ \\
Imipenem & $5(1.0)$ \\
Other & $27(5.1)$ \\
\hline Adequacy of initial empirical treatment & $369(70.3)$ \\
Clinical improvement to initial antibiotic & $369(70.3)$ \\
The switch of initial treatment to alternative & $156(29.7)$ \\
treatment &
\end{tabular}

in a nursing home or elderly care center, history of recurrent UTI, history of hospitalization during previous 12 months, diabetes, chronic renal failure, cerebrovascular accident, solid organ tumor, hematological malignancy, coronary artery disease, hypertension, Alzheimer's disease, BPH, chronic liver disease, Parkinson's disease, hypothyroidism, number of comorbid disease, fever, hypothermia, the amount of growth, the Gram-staining characteristics of the microorganism, Gramnegative microorganism, ESBL positivity in Gram-negative microorganisms, Gram-positive microorganism, and comorbid bacteremia, number of white blood cell, CRP, blood sugar and serum creatinine ( $p>0.05)$.

The data analysis revealed mortality to be significantly higher in patients with advanced age, hospital admissions through the emergency department, urosepsis, urinary catheter, functional dependency, admission to the ICU, COPD, congestive heart failure, increase in the $\mathrm{CCl}$, the absence of urinary symptoms, altered-state of consciousness and hypotension, IEAT, increased respiratory rate and heart rate, and increased blood urea nitrogen level $(p<0.05)$. Multivariate analysis was performed for all the significant variables in the univariate analysis. The presence of COPD, older age, admission to the ICU, and IEAT were independent factors that significantly affected mortality (the factors influencing mortality in the UTI patients being followed-up is shown in Table 5).

\section{Discussion}

In this study, the leading causative agents of UTI were Gramnegative microorganisms $(88 \%)$, E. coli having the highest prevalence, followed by $K$. pneumoniae. In fact, E. coli was the most common causative agent in studies evaluating UTI that had developed in the elderly, similar to our study ${ }^{[6,12,15-18]}$. While ceftriaxone was the most frequently preferred antibiotic for empirical treatment (42.5\%) in our study, the sensitivity of Gram-negative microorganisms to ceftriaxone was only $38.4 \%$. Although ciprofloxacin was preferred in approximately $8 \%$ of our patients for empirical treatment, the susceptibility rate of Gram-negative microorganisms to the drug was $45 \%$. A Turkish study reported that the sensitivity of Gram-negative microorganisms in CA-UTI to ceftriaxone and ciprofloxacin were $44.6 \%$ and $38 \%$, respectively ${ }^{[19]}$. In our study, higher resistance rates found in Gram-negative microorganisms to either ceftriaxone or ciprofloxacin could explain the higher IEAT rate.

Mahesh et al. ${ }^{[20]}$ reported that the rate of CA-UTI in elderly patients was $56.2 \%$ and higher ESBL rates were the most troublesome findings due to multiple antibiotic resistance. Esparcia et al. ${ }^{[6]}$ reported that the ESBL rates for E. coli and K. pneumoniae were $16.8 \%$ and $32.2 \%$, respectively, in uropathogens obtained from hospitalized patients. In our study, the ESBL rate in Gram-negative microorganisms was 56.3\%, which was $56.3 \%$ and $69 \%$ for E. coli and K. pneumoniae, respectively. Another Turkish study reported the ESBL rates in E. coli and $K$. pneumoniae strains obtained from these patients followed-up between 2006 and 2007 were 22\%[21]. A study conducted in Turkey emphasized that ESBL-positive E. coli 
Table 4. The factors affecting the adequate initial empirical antibiotherapy

\begin{tabular}{|c|c|c|c|c|c|}
\hline Characteristics & $\begin{array}{l}\text { Treatment } \\
\text { adequate }\end{array}$ & $\begin{array}{l}\text { nitiated } \\
\text { adequate }\end{array}$ & $\begin{array}{l}\text { Univariate } \\
\text { significance }\end{array}$ & $\begin{array}{l}\text { Univariate OR (95\% } \\
\text { CI) }\end{array}$ & $\begin{array}{l}\text { Multivariate OR }(95 \% \\
\mathrm{CI})^{*}\end{array}$ \\
\hline $\begin{array}{l}65-74 \\
75-84 \\
\geq 85\end{array}$ & \begin{tabular}{|l|}
$175(76.8)$ \\
$134(66.0)$ \\
$60(63.8)$ \\
\end{tabular} & $\begin{array}{l}53(23.2) \\
69(34.0) \\
34(36.2)\end{array}$ & 0.016 & $\begin{array}{l}1.700(12.114-2.595) \\
1.871(1.111-3.150)\end{array}$ & $\begin{array}{l}1.354(0.835-2.197) \\
1.141(0.616-2.116)\end{array}$ \\
\hline $\begin{array}{l}\text { Diagnosis of the patient* } \\
\text { Pyelonephritis } \\
\text { Urosepsis } \\
\text { Septic shock associated with urinary tract } \\
\text { infection }\end{array}$ & $\begin{array}{l}284(73.2) \\
78(62.9) \\
7(53.8)\end{array}$ & $\begin{array}{l}104(26.8) \\
46(37.1) \\
6(46.2)\end{array}$ & 0.039 & $\begin{array}{l}1.610(1.050-2.471) \\
2.341(0.769-7.126)\end{array}$ & $\begin{array}{l}1.225(0.716-2.097) \\
1.291(0.358-4.649)\end{array}$ \\
\hline Presence of temporary catheter & $135(62.5)$ & $81(37.5)$ & 0.005 & $1.905(1.270-2.858)$ & $1.849(1.175-2.911)$ \\
\hline Dependent functional status & $121(63.7)$ & $69(36.3)$ & 0.013 & $1.626(1.108-2.385)$ & $1.200(0.731-1.971)$ \\
\hline Patients with history of recurrent UTI & $119(81.5)$ & 27 (18.5) & 0.001 & $2.274(1.423-3.634)$ & $2.350(1.301-3.220)$ \\
\hline $\begin{array}{l}\text { Patients with genitourinary intervention } \\
\text { and/or surgery before hospital admission }\end{array}$ & $69(80.2)$ & $17(19.8)$ & 0.027 & $1.881(1.066-3.317)$ & $1.322(0.659-2.653)$ \\
\hline $\begin{array}{l}\text { Patients whom follow-up in the intensive } \\
\text { care unit }\end{array}$ & $89(58.1)$ & $64(41.9)$ & 0.001 & $2.189(1.470-3.259)$ & $2.043(1.288-3.240)$ \\
\hline Presence of benign prostate hypertrophy & $358(71.2)$ & $145(28.8)$ & 0.033 & $2.469(1.047-5.821)$ & $3.280(81.216-8.845)$ \\
\hline $\begin{array}{l}\mathrm{CCl}^{*} \\
0-1 \\
2-3 \\
4-5 \\
6-7 \\
\geq 8\end{array}$ & $\begin{array}{l}56(75.7) \\
101(75.4) \\
114(69.9) \\
57(57.6) \\
41(74.5) \\
\end{array}$ & $\begin{array}{l}18(24.3) \\
33(24.6) \\
49(30.1) \\
42(42.4) \\
14(25.5) \\
\end{array}$ & 0.028 & $\begin{array}{l}1.017(0.525-1.968) \\
1.337(0.714-2.505) \\
2.292(1.180-4.453) \\
1.062(0.474-2.379) \\
\end{array}$ & $\begin{array}{l}0.845(0.394-1.812) \\
0.979(0.475-2.018) \\
1.616(0.752-3.470) \\
1.011(0.409-2.501) \\
\end{array}$ \\
\hline $\begin{array}{l}\text { Treatment* } \\
\text { Ciprofloxacin } \\
\text { Ampicillin-sulbactam } \\
\text { Ceftriaxone } \\
\text { Moxifloxacin } \\
\text { Levofloxacin } \\
\text { Other }\end{array}$ & $\begin{array}{l}31(70.5) \\
7(58.3) \\
126(56.5) \\
6(54.5) \\
2(40) \\
15(55.6\end{array}$ & $\begin{array}{l}13(29.3) \\
5(41.7) \\
97(43.5) \\
5(45.5) \\
3(60) \\
12(44.6)\end{array}$ & 0.001 & $\begin{array}{l}6.29(1.892-20.918) \\
10.714(2.32-49.49) \\
11.548(4.056-32.873) \\
12.50(2.627-59.472) \\
22.5(2.88-175.764) \\
12.00(3.386-42.524)\end{array}$ & $\begin{array}{l}8.396(2.425-29,064) \\
13.988(2.889-67.736) \\
13.904(4.766-40.56) \\
15.733(3.166-78.171) \\
28.604(3.396-240.897) \\
13.346(3.649-48.803)\end{array}$ \\
\hline
\end{tabular}

UTI: Urinary tract infections, CCl: Charlson Comorbidity Index, OR: Odds ratio, $\mathrm{Cl}$ : Confidence interval

${ }^{*}$ Age 65-74, pyelonephritis, $\mathrm{CCl}$ 0-1 and treatment with carpabenem used as a referans in multivariate analysis.

were vital, particularly in CO-HCA UTI and that ertapenem should be selected in the empirical treatment ${ }^{[22]}$. The ESBL rates in Turkey are more consistent with those reported from countries in Asia, Latin America, and the Middle East ${ }^{[19]}$. Koksal et al. ${ }^{[19]}$ reported that fluoroquinolones and cephalosporins had reduced therapeutic options for empirical UTI therapy due to the low susceptibility rates to these antibiotics and high ESBL rates among $E$. coli and $K$. pneumoniae strains. Similarly, in our study, the use of antibiotics other than piperacillin-tazobactam and carbapenem correlated with IEAT. Based on these results, empirical treatment options should be reviewed in elderly upper UTI patients in Turkey. Piperacillin-tazobactam and carbapenem are more convenient options for empirical treatment in upper UTI in elderly.

This study established a direct correlation between IEAT and mortality in elderly patients with upper UTI. Likewise, Esparcia et al. ${ }^{[6]}$ determined a significant correlation between IEAT and mortality in elderly patients with upper UTI who were followedup in an internal medicine clinic. Chin et al. ${ }^{[15]}$ reported that the IEAT rate was significantly higher in patients with mortality ${ }^{[15]}$. In previous studies evaluating IEAT in UTI, the IEAT rate was 24.4$29.3 \%{ }^{[6]}$. Likewise, the IEAT rate in our study was $29.7 \%$, which was significantly higher in patients with sepsis than in those with pyelonephritis. This finding suggests that our empirical treatment choices, particularly in patients with acute disease such as urosepsis, warrant revision.

In this study, IEAT directly correlated with the presence of a urinary catheter, admission to the ICU, BPH, and the use of antibiotics other than piperacillin-tazobactam and carbapenem. The use of a urinary catheter has been defined as a risk factor for IEAT in UTI ${ }^{[16]}$. Esparcia et al. ${ }^{[6]}$ reported that the IEAT rate in the group using a urinary catheter was 40\%, which was consistent with our study (33.4\%). The incidence of resistant microorganisms in UTI occurring in patients with a history 
Table 5. The factors affecting mortality in the patients followed-up with a diagnosis of urinary tract infections

\begin{tabular}{|c|c|c|c|c|c|}
\hline \multirow{2}{*}{$\begin{array}{l}\text { Characteristic } \\
\text { Age }^{*} \\
65-74 \\
75-84 \\
\geq 85 \\
\end{array}$} & \multicolumn{2}{|c|}{$\begin{array}{l}\text { Group comparisons } \\
\text { CureDeath }\end{array}$} & \multirow{2}{*}{$\begin{array}{l}\begin{array}{l}\text { Univariate } \\
\text { significance }\end{array} \\
0.001\end{array}$} & \multirow{2}{*}{\begin{tabular}{|l|}
$\begin{array}{l}\text { Univariate OR } \\
\text { (95\% CI) }\end{array}$ \\
$1.448(0.729-2.877)$ \\
$3.581(1.763-7.274)$ \\
\end{tabular}} & \multirow{2}{*}{\begin{tabular}{|l|}
$\begin{array}{l}\text { Multivariate OR } \\
(\mathbf{9 5} \% \mathrm{CI})^{*}\end{array}$ \\
$1.125(0.506-2.502)$ \\
$2.816(1.185-6.693)$ \\
\end{tabular}} \\
\hline & $\begin{array}{l}212(93.0) \\
183(90.1) \\
74(78.7) \\
\end{array}$ & $\begin{array}{l}16(7.0) \\
20(9.9) \\
20(21.3)\end{array}$ & & & \\
\hline $\begin{array}{l}\text { Admission from } \\
\text { Emergency department } \\
\text { Outpatient clinic }\end{array}$ & $\begin{array}{l}308(86.0) \\
161(96.4) \\
\end{array}$ & $\begin{array}{l}50(14.0) \\
6(3.6) \\
\end{array}$ & 0.001 & $4.326(1.829-10.37)$ & $1.053(0.32-3.340)$ \\
\hline $\begin{array}{l}\text { Diagnosis of the patient } \\
\text { Pyelonephritis* } \\
\text { Urosepsis } \\
\text { Septic shock }\end{array}$ & $\begin{array}{l}359(92.5) \\
100(80.6) \\
10(76.9) \\
\end{array}$ & $\begin{array}{l}29(7.5) \\
24(19.4) \\
3(23.1) \\
\end{array}$ & 0.001 & $\begin{array}{l}2.917(1.656-5.33) \\
3.714(0.968-14.24) \\
\end{array}$ & $\begin{array}{l}0.877(0.337-3.279) \\
0.767(0.129-4.542)\end{array}$ \\
\hline Presence of temporary urinary catheter & $179(82.9)$ & $37(17.1)$ & 0.001 & $3.073(1.634-5.778)$ & $1.426(0.594-3.424)$ \\
\hline Dependent functional status & $160(84.2)$ & $30(15.8)$ & 0.004 & $0.228(1.274-3.896)$ & $1.203(0.430-3.364)$ \\
\hline Patients whom follow-up in the ICU & $105(68.6)$ & $48(31.4)$ & 0.001 & $20.800(9.541-45.34)$ & 14.831 (6.636-33.148) \\
\hline $\begin{array}{l}\text { Presence of chronic obstructive pulmonary } \\
\text { disease }\end{array}$ & 87 (81.3) & 20 (18.7) & 0.003 & 2.439 (1.347-4.419) & $2.278(1.106-4.691)$ \\
\hline Presence of congestive heart failure & 87 (81.3) & 20 (18.7) & 0.003 & $2.439(1.347-4.419)$ & $1.287(0.514-3.218)$ \\
\hline $\begin{array}{l}\mathrm{CCl}^{*} \\
0-1 \\
2-3 \\
4-5 \\
6-7 \\
\geq 8\end{array}$ & $\begin{array}{l}68(91.9) \\
123(91.8) \\
151(92.6) \\
84(84.8) \\
43(78.2)\end{array}$ & $\begin{array}{l}6(8.1) \\
11(8.2) \\
12(7.4) \\
15(15.2) \\
12(21.8)\end{array}$ & 0.014 & $\begin{array}{l}1.014(0.359-2.861) \\
0.901(0.324-2.500) \\
2.024(0.745-5.497) \\
3.163(1.105-9.054)\end{array}$ & $\begin{array}{l}0.979(0.255-3.751) \\
0.591(0.152-2.301) \\
1.001(0.249-4.022) \\
2.500(0.539-11.594)\end{array}$ \\
\hline Absence of urinary symptom & $127(82.5)$ & $27(17.5)$ & 0.004 & $2.339(1.305-4.190)$ & $1.070(0.448-2.556)$ \\
\hline Heart rate [min-max (median)] & $52-150(88)$ & 62-188 (90) & 0.008 & $1.025(1.010-1.041)$ & $1.507(1.010-2.041)$ \\
\hline Respiratory rate [min-max (median)] & 8-56 (20) & $14-35(20)$ & 0.018 & 1.043 (0.996-1.091) & $0.978(0.901-2.240)$ \\
\hline Presence of altered-state of consciousness & $132(79.0)$ & $35(21.0)$ & 0.001 & $4.255(2.389-7.579)$ & $1.597(0549-4.644)$ \\
\hline Presence of hypotension & $54(77.1)$ & $16(22.9)$ & 0.001 & $3.0674(1.612-5.861)$ & $1.371(0.544-3.458)$ \\
\hline BUN [min-max (median)] & 9-410 (49) & 8-348 (74.5) & 0.001 & $1.008(1.004-1.012)$ & $1.002(0.996-1.008)$ \\
\hline Inadequate initial treatment & 127(81.4) & $29(18.6)$ & 0.001 & $2.892(1.648-5.075)$ & $2.364(1.204-4.641)$ \\
\hline
\end{tabular}

ICU: Intensive care units, CCl: Charlson comorbidity index, OR: Odds ratio, Cl: Confidence interval, BUN: Blood urea nitrogen, min-max: Minimum-maximum

${ }^{*}$ Age $65-74$, pyelonephritis and $\mathrm{CCl} 0-1$ used as a reference in multivariate analysis.

of invasive procedure, urinary catheter use, and previous antibiotic use is increasing ${ }^{[4]}$. In our study, the IEAT rate was also significantly higher in patients with $\mathrm{BPH}$. We believe that the IEAT rate had increased in these patients because patients with BPH have a history of previous antibiotic use owing to recurrent UTI and exhibit a higher frequency of ongoing genitourinary procedures.

The mortality rate in UTI occurring in elderly patients is $5-33 \% \%^{[6,12,15,17]}$. In our study, the mortality rate was $10.7 \%$, which was consistent with the literature. Esparcia et al. ${ }^{[6]}$ determined an APACHE-II score of $\geq 15$ at the time of admission, the presence of dementia and neoplasia, and IEAT as independent factors that affected mortality. Similarly, in our study, we used $\mathrm{CCl}$ to determine the mortality ratio and when we compared the patients with $\mathrm{CCl}$ score of $>8$ with $\mathrm{CCl}$ score of $<8$, we found a significantly higher mortality rate in patients with $\mathrm{CCl}$ score of $>8$ than the others. Advanced age, the presence of COPD, admission to the ICU and IEAT were determined to be independent variables effective on mortality. All of these mortality-related variables except IEAT could be explained by disease severity and comorbid conditions consistent with previous studies ${ }^{[6,12,15,18]}$.

The first limitation of our study was the SOFA scoring system (used to define organ failure with SOFA scoring system in patients with sepsis and septic shock in the study), which could not be determined as a numerical value, since there was no separate data entry for the SOFA score. The second limitation of the study was that we did not followed-up the patients at the end of the treatment; therefore, we did not evaluate the relapse and reinfection rates. The third limitation was that we did 
not perform the mortality comparative subgroup analysis for the patients who were treated with ceftriaxone/carbapenem/ ciprofloxacin/piperacillin-tazobactam.

\section{Conclusion}

In conclusion, higher ESBL rate in Gram-negative microorganisms, which are the leading causative agents in UTIs occurring in the elderly, is the most critical factor causing IEAT. This study suggests that because ceftriaxone and ciprofloxacin, which are most commonly used for treating UTIs, can cause IEAT due to high resistance rates, these antimicrobial agents should not be used primarily in acute UTI, particularly in the elderly, under the conditions in Turkey. The direct correlation between IEAT and mortality highlights the necessity of elucidating the antibiotic susceptibility profiles of microorganisms most frequently observed in UTIs occurring in geriatric patients to decrease mortality and morbidity associated with these infections.

\section{Ethics}

Ethics Committee Approval: Approval for this study was obtained from the Çukurova University Faculty of Medicine Research Ethics Committee (approval date: 10/02/2017, no: 44).

Informed Consent: Written informed consent was obtained from the study participants.

Peer-review: Externally and internally peer-reviewed.

\section{Authorship Contributions}

Concept: P.K., B.K., F.K., Design: P.K., B.K., F.K., Data Collection or Processing: All authors, Analysis or Interpretation: P.K., B.K., Literature Search: P.K., B.K., Writing: P.K., B.K.

Conflict of Interest: No conflict of interest was declared by the authors.

Financial Disclosure: The authors declared that this study received no financial support.

\section{References}

1. Nicolle LE. Urinary tract infections in the elderly. Clin Geriatr Med. 2009;25:423-36.

2. Juthani-Mehta M, Quagliarello V, Perrelli E, Towle V, Van Ness PH, Tinetti $M$. Clinical features to identify urinary tract infection in nursing home residents: a cohort study. J Am Geriatr Soc. 2009;57:963-70.

3. Evaluation of infection in the older adult. Last accessed date: 2018 Dec 19. Available from: https://www.uptodate.com/contents/evaluationof-infection-in-the-older-adult?search $=$ urinary $\% 20$ tract $\% 20$ infection\%20elderly\&tsource=search_resultEtselectedTitle=1 150\&tusage_ type $=$ default\&display_rank=1\#H1498087

4. Detweiler K, Mayers D, Fletcher SG. Bacteruria and Urinary Tract Infections in the Elderly. Urol Clin North Am. 2015;42:561-8.

5. Yoshikawa TT, Norman DC. Geriatric Infectious Diseases: Current Concepts on Diagnosis and Management. J Am Geriatr Soc. 2017;65:631-41.
6. Esparcia A, Artero A, Eiros JM, Balaguer M, Madrazo M, Alberola J, Nogueira JM. Influence of inadequate antimicrobial therapy on prognosis in elderly patients with severe urinary tract infections. Eur J Intern Med. 2014;25:523-7.

7. Kollef MH. The importance of appropriate initial antibiotic therapy for hospital-acquired infections. Am J Med. 2003;115:582-4.

8. WMA Declaration of Helsinki - Ethical principles for medical research involving human subjects. Last accessed date: $2019 \mathrm{Jul} \mathrm{19.} \mathrm{Available} \mathrm{from:}$ https://www.wma.net/policies-post/wma-declaration-of-helsinki-ethicalprinciples-for-medical-research-involving-human-subjects/

9. Aguilar-Duran $S$, Horcajada JP, Sorli L, Montero M, Salvadó M, Grau S, Gómez J, Knobel H. Community-onset healthcare-related urinary tract infections: comparison with community and hospital-acquired urinary tract infections. J Infect. 2012;64:478-83.

10. Catheter-associated urinary tract infection in adults. Last accessed date: 2019 Jul 19. Available from: https://www.uptodate. $\mathrm{com} /$ contents/catheter-associated-urinary-tract-infectioninadults?search=URINARY\%20INFECTIONS\%20catheterEtsource=search resultttselectedTitle $=1$ 150\&tusage_type $=$ defaulttdisplay_rank=1

11. Singer $M$, Deutschman CS, Seymour CW, Shankar-Hari M, Annane $D$, Bauer M, Bellomo R, Bernard GR, Chiche JD, Coopersmith CM, Hotchkiss RS, Levy MM, Marshall JC, Martin GS, Opal SM, Rubenfeld GD, van der Poll T, Vincent JL, Angus DC. The Third International Consensus Definitions for Sepsis and Septic Shock (Sepsis-3). JAMA. 2016;315:801-10.

12. Tal $S$, Guller V, Levi $S$, Bardenstein R, Berger D, Gurevich I, Gurevich A. Profile and prognosis of febrile elderly patients with bacteremic urinary tract infection. J Infect. 2005;50:296-305.

13. European Committee on Antimicrobial Susceptibility Testing. Breakpoint tables for interpretation of MICs and zone diameters. Last accessed date: 2019 Jul 19. Available from: http://www.eucast.org/fileadmin/src/media/ PDFs/EUCAST_files/Breakpoint_tables/v_8.0_Breakpoint_Tables.pdf

14. EUCAST guidelines for detection of resistance mechanisms and specific resistances of clinical and/or epidemiological importance. Last accessed date: 2019 Jul 19. Available from: http://www.eucast.org/fileadmin/src/ media/PDFs/EUCAST_files/Resistance_mechanisms/EUCAST_detection_ of_resistance_mechanisms_170711.pdf

15. Chin BS, Kim MS, Han SH, Shin SY, Choi HK, Chae YT, Jin SJ, Baek JH, Choi JY, Song YG, Kim CO, Kim JM. Risk factors of all-cause in-hospital mortality among Korean elderly bacteremic urinary tract infection (UTI) patients. Arch Gerontol Geriatr. 2011;52:50-5.

16. Wright SW, Wrenn KD, Haynes M, Haas DW. Prevalence and risk factors for multidrug resistant uropathogens in ED patients. Am J Emerg Med. 2000;18:143-6

17. Alpay $\mathrm{Y}$, Aykin N, Korkmaz P, Gulduren HM, Caglan FC. Urinary tract infections in the geriatric patients. Pak J Med Sci. 2018;34:67-72.

18. Gopal GK, Wilson BP, Viggeswarpu S, Sathyendra S, lyyadurai R, Visvanathan R, Mathews KP. Clinical Profile and Predictors of Outcomes in Older Inpatients with Pyelonephritis in a Tertiary Care Hospital in Southern India. J Clin Diagn Res. 2015;9:5-7.

19. Koksal I, Yilmaz G, Unal S, Zarakolu P, Korten V, Mulazimoglu L, Tabak F, Mete B, Oguz VA, Gulay Z, Alp E, Badal R, Lob S. Epidemiology and susceptibility of pathogens from SMART 2011-12 Turkey: evaluation of hospital-acquired versus community-acquired urinary tract infections and ICU- versus non-ICU-associated intra-abdominal infections. J Antimicrob Chemother. 2017;72:1364-72.

20. Mahesh E, Medha $Y$, Indumathi VA, Kumar PS, Wasim Khan M, Punith K. Community-acquired urinary tract infection in the elderly. BMJP. 2011;4:6-9. 
21. Kurtaran B, Candevir A, Tasova Y, Kibar F, Inal AS, Komur S, Aksu HS. Antibiotic resistance in community-acquired urinary tract infections: prevalence and risk factors. Med Sci Monit. 2010;16:246-51.

22. Saltoglu N, Karali R, Yemisen M, Ozaras R, Balkan II, Mete B, Tabak F, Mert A, Hondur N, Ozturk R. Comparison of community-onset healthcare- associated and hospital-acquired urinary infections caused by extendedspectrum beta-lactamase-producing Escherichia coli and antimicrobial activities. Int J Clin Pract. 2015;69:766-70. 